\title{
The French contribution to the Global Climate Observing System
}

\author{
R. Juvanon du Vachat \\ Société Météorologique de France, 1, Quai Branly 75007, Paris, France \\ Received: 18 October 2010 - Revised: 27 January 2011 - Accepted: 8 February 2011 - Published: 9 March 2011
}

\begin{abstract}
France is participating fully in the Global Climate Observing System (GCOS). It incorporates the following four components: meteorological and atmospheric, oceanic, terrestrial, spatial, which will be briefly presented, especially in relation with the monitoring of the climate. The presentation will give an overview of the general principles governing the GCOS system and particularly the concepts used to maintain efficiently this climate observing system for a long period of time ("from research networks to operational networks"). The presentation will cover all the four components of the GCOS system. The whole report has been published in the Fifth National Communication from France to the UNFCCC (United Nations Framework Convention on Climate Change). The presentation will give an overview of the different networks of these four domains devoted to the monitoring of climate and maintained by France and highlighting the strengths and weaknesses of this climate observing system.
\end{abstract}

\section{Introduction and general considerations}

This report gives an overview of the ground-based and space-born activities in France in response to the Implementation Plan of the Global Climate Observing System (GCOS) (www.wmo.int/pages/prog/gcos/Publications/ gcos-92_GIP.pdf) as specified for the three specific domains (atmosphere, ocean, terrestrial). The GCOS programme in France is mainly driven by Mété-France for the atmospheric domain, but other institutions contribute in the field of climate for specific observations such as of the atmospheric composition, and in the oceanography and the terrestrial domain (glaciers). A number of observations are done for research purposes, and the question of "how to ensure these observations in the long term?" is regularly addressed. Also, in some cases climate observation networks are developed along a European structure (Framework Programme), and the national level is not relevant! Another item for consideration is the question of historical data, which are essential to understand present and future climate (we refer to paleoclimatic research and data rescue programmes). Finally the issue of the contributions to the GCOS programme in developing countries, especially in Africa, has been considered within the international research

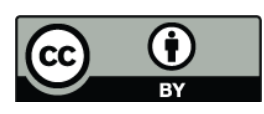

Correspondence to:

R. Juvanon du Vachat

(regis.juvanon-du-vachat@meteo.fr) project and field campaign AMMA concerning the study of West African Monsoon. An inventory of all these observations for climate is compiled every five years for the National Communication under the UN Framework Convention on Climate Change (UNFCCC), in the chapter "Research and Systematic Observation". The last update is the 5th National Communication, which can be found at the UNFCCC website (www.unfccc.int, see National Reports) or at the French website: http://www.developpement-durable.gouv.fr/ IMG/pdf/5e_communication_changement_climatique.pdf.

\section{Atmospheric domain}

This is a domain mainly operated by Météo-France. The whole system consists of six GSN stations (surface observations) in mainland France and fourteen ones for overseas territories, all producing monthly CLIMAT messages. For GUAN stations (upper-air observations) the network consists of nine stations in overseas territories (no GUAN in France itself) producing monthly CLIMAT TEMP messages. The ten GCOS monitoring principles (see the GCOS Implementation Plan) have been integrated in the quality management system for observations of Météo-France. In recent years an important programme on data rescue and the reconstitution of long time series have been started, including the African Database (observations of 14 African countries). France is 
also collaborating with the MEDARE project (Spain) aiming at recovering climate observations in the Mediterranean area.

Concerning the chemistry of the atmosphere the RAMCES network developed by LSCE (Laboratoire des Sciences du Climat et de l'Environnement) is worthwhile for computing the $\mathrm{CO}_{2}$ budget over a given area (region, continent). This network operates at Amsterdam Island (Indian Ocean), Mace Head (Ireland), Puy de Dôme and Biscarosse (mainland France), with some flasks with air samples collected in twelve sites located around the world. Similar measurements are done for other greenhouse gases in the frame of this RAMCES programme. All these measurements contribute to the GAW network. As an example of an application of these measurements, Bousquet et al. (2006) show the contribution of anthropogenic and natural sources to the atmospheric methane variability. In addition, there are four stations in continental France measuring precipitation chemistry, radiation and tropospheric ozone (BAPMON network). Stratospheric and upper tropospheric ozone is measured at three sites overseas (NDACC network) and at different sites located around the globe (Finland, Russia, Greenland and Brazil). The operating agencies are INSU-CNRS for NDACC and LSCE for RAMCES.

Other initiatives in the field of monitoring the atmospheric composition in which France plays a role are the following European projects. The project GEOMON (Global Earth Observation and MONitoring, www.geomon.eu) concerns the measurements of greenhouse gases, atmospheric pollution, aerosols and stratospheric ozone; MACC (Monitoring Atmospheric Composition and Change) follows GEMS (20052009), and tries to build high-level monitoring of greenhouse gases, reactive gases and aerosols, including dataassimilation and multi-model forecasting; ICOS (Integrated Carbon Observing Strategy, http://www.icos-infrastructure. $\mathrm{eu} /$ ) is a pan-European system for observation of greenhouse gases over the European continent and adjacent regions (Siberia, Africa) with various sensors (towers, planes, satellite), with the aim of producing daily maps of concentration of $\mathrm{CO}_{2}$ and other greenhouse gases.

\section{Oceanic domain}

Under the Global Ocean Observation System (GOOS) the French contribution comprises the following measurements: voluntary and occasional observing ships (VOS), ocean gauges (GLOSS network), floating and anchored weather buoys, and sub-surface floaters like ARGO (Coriolis Project). France also maintains the PIRATA observation system (anchored buoys) in the tropical Atlantic Ocean (Bourlès et al., 2008) and contributes to TAO for the Pacific Ocean (IRD). We would like to emphasize the operational approach followed in oceanic observations. The seven French agencies involved in oceanography (CNES, CNRS, IFREMER, IPEV, IRD, Météo-France and SHOM) are joining forces to develop

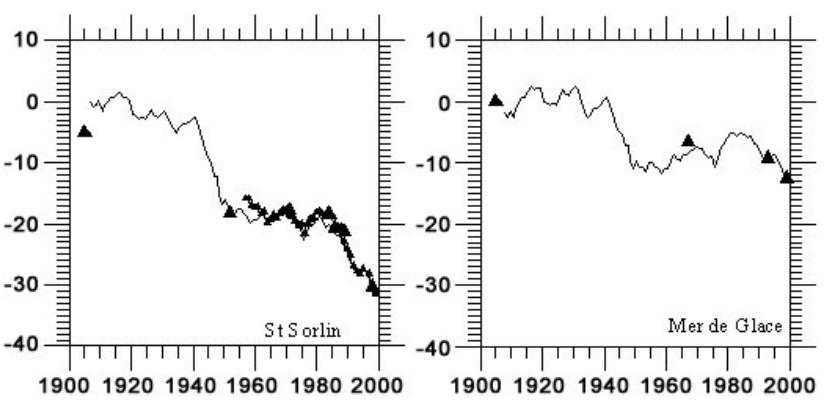

Figure 1. Cumulative specific net balance (m water-equivalent) from reconstruction (solid line), from direct measurements (small triangles) and from maps (large triangles) for two glaciers in the Alps (Vincent, 2002).

a complete and coherent system of operational oceanography based on three projects: satellite altimetry (JASON), global numerical modelling with data assimilation (MERCATOR) and in situ measurements (Coriolis). The Coriolis project offers the operational structure for acquiring, collecting, validating and distributing world ocean data (temperature, salinity and current profiles) responding to the needs of modellers (MERCATOR) and of the scientific community (CLIVAR programme). For the main results of this project see the Mercator website (http://www.mercator-ocean.fr/).

\section{Terrestrial observations}

Under the Global Terrestrial Network (GTN) the French contribution deals with the observations of mountain glaciers and measurements of carbon fluxes in terrestrial ecosystems (Fluxnet). Mountain glaciers are studied in France and abroad by LGGE, IRD, IPEV and CEMAGREF. The "Glacio-Clim" Observatory, which is labelled as "Observatoire de Recherche en Environnement", consists in monitoring some glaciers at different latitudes (which implies different climate regimes). The sites concerned are in mainland France (five glaciers), in Bolivia and Ecuador, and in Antarctica (two glaciers). Vincent (2002) gives an example of the monitoring of four glaciers in France (evolution of the mass balance during a century, Fig. 1). For the "GlacioClim" Observatory we refer to the website http://www-lgge. ujf-grenoble.fr/ServiceObs/contexte-angl.htm.

France is also actively participating in measuring carbon fluxes in terrestrial ecosystems (six sites with different land cover) carried out under the Fluxnet international programme and the various programmes connected with the Carboeurope project. That integrated project aims at determining the role of the European continent in the global carbon cycle. The agencies involved in this programme are: INRA, CNRM, and LSCE. Ciais et al. (2005) give an example of such measurements concerning the heat and drought event of summer 2003 in Europe. More specific experiments have been conducted 
in the Southwest France in 2005 ("Les Landes", Dolman et al., 2006) with various land cover. Forest ecosystems have been systematically observed by the National Forestry Inventory (IFN) every ten years since 1970, through a survey (sort and volume of trees) put in place after the damage caused by acid rain.

\section{Space component}

Concerning the space observations, we can mention the specific response to the GCOS Implementation Plan done by the Committee on Earth Observing Satellites (CEOS), in which the Centre National d'Etudes Spatiales (CNES) is taking a contributing part.

\section{GCOS in Africa}

After the GCOS regional meeting held in Niamey (March 2003), a number of discussions have arisen on how to restore the deficient networks for climate observations, especially in that part of Africa (West and Central Africa; see Parker et al., 2008). It is important to mention the AMMA experiment (Redelsperger et al., 2006) conducted in that region 2005-2007, leading to restore some radiosoundings and fine scale measurements covering meteorology but also hydrology and aerosols. In the frame of the RIPIECSA experiment the sustainability of the meteorological observational network has been ensured for one more year, but the long term maintenance of that network remains an open question. Finally a new project supported by FFEM (French component of GEF), along with other organizations (as ACMAD) has been proposed, in order to comply with G8 commitments for France ("Climate and observations for Africa"). That project is mainly built on the question of "Climate adaptation for Africa", in the sectors of agriculture, water resources and health, but also the prevention of the consequences of severe weather and climate events. A similar project has been formulated and supported (July 2007) by this FFEM agency in the context of "adaptation", covering the five islands of the west part of the Indian Ocean (Réunion, Mauritius, Madagascar, Comoros, Seychelles). It is a pilot project in the climate change context of "Impacts, Adaptation and Vulnerability".

\section{Conclusions}

As a conclusion we observe that a great number of institutions are involved in climate observations in France, including Météo-France and other agencies connected to the Ministry in charge of Environment and to the Ministry in charge of Research. All these institutions are mentioned below. Coordination is necessary and partially fulfilled under the GEO-GMES French coordination group, at institutional level. We refer again to the French web link to the fifth National Communication, where the detailed inventory of the networks can be found (http://www.developpement-durable.gouv.fr/IMG/ pdf/5e_communication_changement_climatique.pdf) with the new reporting format (Chapter 8 and Annex XI for the Tables). Two French publications have also been written for different workshops held in France (Juvanon du Vachat, 2003, 2004) illustrating various aspects of climate and relative to the third National Communication (2001).

\section{French institutions involved in climate observations}

CEMAGREF: Centre d'Etudes du Machinisme Agricole, du Génie Rural et des Eaux et Forêts

CNES: Centre National d'Etudes Spatiales

CNRS: Centre National de la Recherche Scientifique

CNRM: Centre National de Recherches Météorologiques

(Météo-France)

IFN: Inventaire Forestier National

IFREMER: Institut Français de Recherche et d'Exploitation de la MER

INRA: Institut National de la Recherche Agronomique

INSU: Institut National des Sciences de l'Univers

IPEV: Institut Paul Emile Victor (Polar Institute)

IRD: Institut de Recherche pour le Développement

(former ORSTOM)

LGGE: Laboratoire de Glaciologie et de

Géophysique de l'Environnement

LSCE: Laboratoire des Sciences du Climat et de

l'Environnement

Météo-France (Direction de la Climatologie)

SHOM: Service Hydrographique et Océanographique de la Marine

\section{Acronyms not explained in the text}

ACMAD: African Centre for Meteorological Applications for Development

AMMA: African Monsoon Multidisciplinary Analysis

ARGO: Array for Real time Geostrophic Oceanography

BAPMON: Background Air Pollution MONitoring

CLIVAR: Climate Variability and Predictability

FFEM: Fonds Français de l'Environnement Mondial

GAW: Global Atmosphere Watch

GCOS: Global Climate Observing System

GEF: Global Environment Fund

GEMS: Global Earth-system Monitoring using Satellite and in-situ data

GEO: Group on Earth Observations

GEOMON: Global Earth Observation and MONitoring of the atmosphere

GLOSS: Global Sea Level Observing System

GODAE: Global Ocean Data Assimilation Experiment

GSN: GCOS Surface Network 
GUAN: GCOS Upper Air Network

MACC: Monitoring Atmospheric Composition and Change MEDARE: MEditerranean climate DAta REscue

NDACC: Network for the Detection of Atmospheric Composition Change

PIRATA: Prediction and Research Moored Array

in the Atlantic

RAMCES: Réseau Atmosphérique de Mesure des Composés à Effet de Serre

RIPIECSA: Recherche Interdisciplinaire et Participative sur les Interactions entre les

Ecosystèmes, le Climat et les Sociétés d'Afrique de l'Ouest TAO: Tropical Atmosphere Ocean (Pacific Ocean)

UNFCCC: United Nations Framework Convention on Climate Change

Edited by: W. A. Monna

Reviewed by: P. Bessemoulin and another anonymous referee

\section{SC $\mid$ nat $^{\mathbf{t}} \begin{aligned} & \text { The publication of this article is sponsored } \\ & \text { by the Swiss Academy of Sciences. }\end{aligned}$}

\section{References}

Bourlès, B., Lumpkin, R., McPhaden, M. J., Hernandez, F., Nobre, P., Campos, E., Yu, L., Planton, S., Busalacchi, A., Moura, A. D., Servain, J., and Trotte, J.: The Pirata program: History, accomplishments and future directions, B. Am. Meteorol. Soc., 89, 1111-1125, 2008.

Bousquet, P., Ciais, P., Miller J. B., Dlugokencky E. J., Hauglustaine, D. A., Prigent, C., Van der Werf, G. R., Peylin, P., Brunke, E.-G., Carouge, C., Langenfelds, R. L., Lathière, J., Papa, F., Ramonet, M., Schmidt, M., Steele, L. P., Tyler, S. C., and White, J.: Contribution of anthropogenic and natural sources to atmospheric methane variability, Nature, 443, 439-443, 2006.
Ciais, P., Reichstein, M., Viovy, N., Granier, A., Ogée, J., Allard, V., Aubinet, M., Buchmann, N., Bernhofer, C., Carrara, A., Chevallier, F., De Noblet, N., Friend, A. D., Friedlingstein, P., Grünwald, T., Heinesch, B., Keronen, P., Knohl, A., Krinner, G., Loustau, D., Manca, G., Matteucci, G., Miglietta, F., Ourcival, J. M., Papale, D., Pilegaard, K., Rambal, S., Seufert, G., Soussana, J. F., Sanz, M. J., Schulze, E. D., Vesala T., and Valentini, R.: Europe-wide reduction in primary productivity caused by the heat and drought in 2003, Nature, 437, 529-533, 2005.

Dolman, A. J., Tolk, L., Ronda, R., Noilhan, J., Sarrat, C., Brut, A., Piguet, B., Durand, P., Butet, A., Jarosz, N., Brunet, Y., Loustau, D., Lamaud, E., Miglietta, F., Gioli, B., Magliulo, V., Esposito, M., Gerbig, C., Körner, S., Glademard, P., Ramonet, M., Ciais, P., Neininger, B., Hutjes, R. W. A., Elbers, J. A., Macatangay, R., Schrems, O., Pérez-Landa, G., Sanz, M. J., Scholz, J., Facon, G., Ceschia, E., and Beziat, P.: The Carbo-Europe Regional Experiment Strategy, B. Am. Meteorol. Soc., 87, 1367-1379, 2006.

Juvanon du Vachat, R.: Le système mondial d'observation du climat, Contribution française, Annales Assoc. Int. de Climatologie, 15, 458-464, www.climato.be/aic, 2003.

Juvanon du Vachat, R.: Le système mondial d'observation du climat, Atelier Expérimentation et Instrumentation, Paris, 6 pp., aei2004.dt.insu.cnrs, 2004.

Parker, D. J., Fink, A., Janicot, S., Ngamini, J.-B., Douglas, M., Afiesimana, E., Agusti-Panareda, A., Beljaars, A., Dide, F., Diedhiou, A., Lebel, T., Polcher, J., Redelsperger, J.-L., Thorcroft, C., and Wilson, G.A.: The AMMA radiosonde programme and its implications for the future of atmospheric monitoring over Africa, B. Am. Meteorol. Soc., 89, 1015-1027, 2008.

Redelsperger, J.-L., Thorncroft,C. D., Diedhiou, A., Lebel, T., Parker, D. J., and Polcher, J.: African Monsoon Multidisciplinary Analysis : An international research project and field campaign, B. Am. Meteorol. Soc., 87, 1739-1746, 2006.

Vincent C.: Influence of climate change over the 20th century on four French glacier mass balances, J. Geophys. Res., 107(D19), ACL4, 1-12, 2002. 